Article

\title{
Determination of the Energy Behaviour in Municipalities with Fewer than 6000 Inhabitants in Badajoz (Spain)
}

\author{
Cosme Segador-Vegas ${ }^{1}$, Justo García-Sanz-Calcedo ${ }^{2, *}$ (D) and Daniel Encinas-Martín ${ }^{3}$ \\ 1 Department of Mechanical, Materials and Energetic Engineering, University of Extremadura, 06006 Badajoz, \\ Spain; csegador@unex.es \\ 2 Department of Graphical Expression, University of Extremadura, 06006 Badajoz, Spain \\ 3 Extremadura Energy Agency, 06005 Badajoz, Spain; dencinas@agenex.org \\ * Correspondence: jgsanz@unex.es; Tel.: +34-924-289-600
}

Received: 15 August 2018; Accepted: 27 August 2018; Published: 30 August 2018

\begin{abstract}
Most of the municipalities in Europe have a population of less than 6000 inhabitants and high energy consumption. In order to reduce consumption, it is necessary to know the energy behaviour of a municipality beforehand. The purpose of this article is to analyse the energy and environmental situation of the municipalities of the province of Badajoz (Spain) and formulates energy efficiency and environmental indicators. The method is based in the analysis of 74 energy audits were carried out between 2012 and 2014 in the corresponding municipalities, and the average final energy consumption was studied in terms of four different variables: area of the municipality, number of inhabitants, cost of energy, and annual $\mathrm{CO}_{2}$ emissions. In addition, a statistical analysis based on variance was carried out. The results obtained show that the average annual energy consumption of a municipality of less than 6000 inhabitants is $300 \mathrm{kWh}$ per inhabitant and $1 \mathrm{kWh}$ per $\mathrm{m}^{2}$ of surface area. A great variability was observed in the average cost of energy for each municipality, between 0.11 and $0.25 € / \mathrm{kWh}$, with an average of $0.17 € / \mathrm{kWh}$. In addition, by statistical methods it was determined that the energy consumption of a municipality is proportional to the surface area that it occupies and its number of inhabitants, proposing an equation that allows determining the final energy consumption according to both variables. This benchmarking is valid to implement energy saving techniques and to prioritize investments in the renovation of the facilities. There are no precedents of similar research studies with such a large number of municipalities.
\end{abstract}

Keywords: energy consumption; municipal energy plans; municipalities; energy benchmarking; buildings projects

\section{Introduction}

The public expenditure of the municipalities of the European Union is equivalent to $19 \%$ of its gross domestic product [1]. Municipalities are an important driver to stimulate the use of more efficient buildings and services [2], as well as to cause behavioural changes in energy consumption in citizens and companies [3], in order to collaborate in sustainable development. The improvement of energy efficiency in the municipalities is one of the measures that can contribute the most to the fulfilment of the energy-saving objectives [4].

In the European Union, Spain is the country with the greatest expenditure on public lighting and its management depends on the municipalities [5]. In Spain, $86 \%$ of the municipalities have less than 6000 inhabitants; therefore, this range is the most interesting in order to analyse its energy consumption in more detail. 
The energy consumption of a municipality presents unique characteristics, due to the diversity of functions of the municipal facilities (schools, libraries, sports facilities, offices, etc.), the organizational variety of the various decision centres and the use of different energy sources [6]. According to the Regional Energy Agency of Andalusia, the existing savings potential in municipal buildings in the region of Andalusia (Spain) exceeds, in most cases, 30\% of its current energy expenditure [7].

Poggi et al. [8] described a methodology for evaluating the energy performance at the municipal level, associated with a case study, although they did not evaluate the average energy consumption of the municipality. Brandoni and Polonara [9] analysed the role of municipal planning in the context of the regional energy planning process, through 12 municipal energy plans developed in urban areas located in the Marche region (Italy).

Rezessy et al. [10] analysed the factors that determine the degree of participation of local authorities in the market of energy services in Bulgaria, Hungary, and Macedonia. They concluded that greater decentralization is the first step to increase the role of local authorities in the energy market.

Sveinbjörnsson et al. [11]. modelled the low $\mathrm{CO}_{2}$ energy supply in a municipality of Denmark, demonstrating that scenarios with low biomass consumption and a high degree of electrification depend less on changes in energy prices

The ENERINTOWN project showed that by remote control of the consumption of electricity and natural gas in public buildings, managed by the municipal authorities of eight European Union countries, it was possible to achieve energy savings of up to $35 \%$, with an average of $12 \%$ [12].

Skujevska et al. [13] identified heat consumers in the municipality of Salaspils (Latvia) through Geographic Information Systems. With the help of a heat map, they determined the areas in which it would be beneficial to expand the existing district heating network, or vice versa, although they did not quantify the municipality's annual energy consumption.

On the other hand, Ferreira [14] analysed the primary consumption of electricity and gas in six municipal buildings typologies, through a survey of local authorities, to evaluate the current procedures and needs of municipal energy managers in terms of data analysis, evaluate the energy performance of the building and identify potential opportunities for energy savings.

Axyonov et al. [15] compared different municipalities in Russia based on their level of energy efficiency. They proposed to group municipalities through fuzzy models to estimate how social, economic, and climatic characteristics affect the use of energy. However, they did not deepen in determining energy reference indicators.

Fiaschi et al. [16] analysed the energy consumption in the municipality of Certaldo (Italy), with 16,000 inhabitants. They found that more than $60 \%$ of electricity consumption was focused on public lighting and more than $13 \%$ on lighting in public schools. With regard to heating, more than $60 \%$ of the consumption of natural gas was used to heat public schools and $18 \%$ in the heating of sport facilities. The high weight of lighting in the energy consumption of a municipality was evidenced in the municipality of Murcia (Spain), where it was found that the street lighting network had more than 90,000 points of light and an installed power exceeding 11 MW [17].

There are no precedents for similar works, analysing so large a number of municipalities. The research carried out in this field to date has been scant. There are only references of studies focused on very small samples, usually from a single municipality, all of them with little or no statistical significance. The lack of reliable data on the average energy consumption of a municipality impedes the authorities' prioritizing investments and identifying their reference consumption, not being able to reward or penalize municipalities whose energy expenditure differs from it.

The objective of this article is to evaluate the energy performance in the municipalities of less than 6000 inhabitants of the province of Badajoz (Spain), and to generate energy consumption indicators that allow knowing their real and environmental energy situation. With these benchmarks, it will be possible to determine the real energy situation of a municipality and propose operational solutions that allow the implementation of energy saving strategies. It will also be possible to make decisions in 
relation to the most profitable application of funds for the renovation of municipal facilities from the point of view of energy savings.

The rest of the paper is structured as follows: The model structure and methodology are introduced in Section 2. In Section 3, the correlation analyses between the final annual energy consumption of a municipality and the indicators considered in the study are presented, along with the results of the analysis of the variance and reference indicators to measure the energy consumption of a municipality. The comparative analysis of different data-driven models and monitoring results are discussed in Section 4, and conclusions are drawn in Section 5.

\section{Materials and Methods}

The method used in the research was focused on the development of energy audits in each municipality studied; then, detailed analysis of the data obtained through inferential statistic was carried out. Seventy-four energy audits carried out in the municipalities of the province of Badajoz (Spain) were analysed. They were financed by the County Council of the province of Badajoz, and coordinated by Extremadura Energy Agency. The audits were carried out between 2012 and 2014, and included the energy consumption of each municipality and its associated expenditure.

The energy audits were implemented by technical staff of the County Council of Badajoz, the Extremadura Energy Agency, and by energy services companies [18]. The processing of the data, its analysis and the present research have been produced under the European project RED URBANSOL, so it has been financed with ERDF Funds through the Cross-Border Cooperation Program Spain and Portugal POCTEP. Thirty-four of the whole number of energy audits corresponded to municipalities between 200 and 1200 inhabitants (45.95\%), 24 between 1201 and $2500(32.43 \%)$, and 16 to municipalities between 2501 and 6000 inhabitants (21.62\%).

The methodology proposed in this work can be observed in Figure 1, and it has two stages: (i) data collection and energy audit coordinated by the Extremadura Energy Agency; and (ii) determination of the energy behaviour in municipalities with fewer than 6000 inhabitants, realised by the authors.

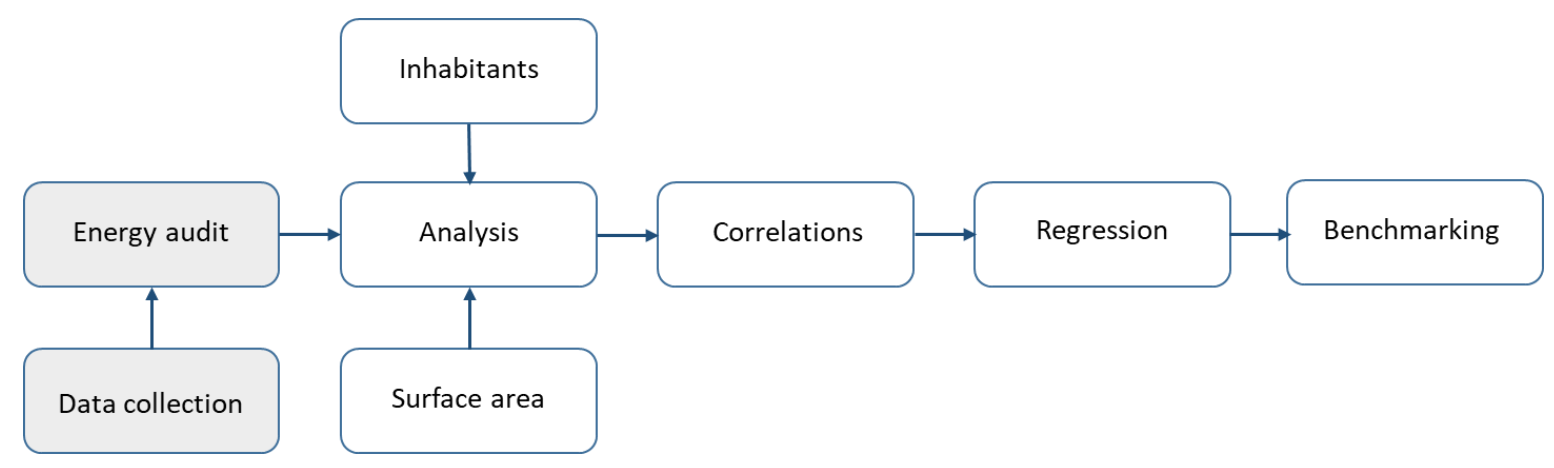

Figure 1. Methodology diagram.

The concept of municipality considered was a public administrative entity composed of a territory of fixed limits, with the population that inhabits it legally regulated [19]. The management of economic expenses and energy consumption of the municipality is public and is carried out in the corresponding town hall. The buildings and facilities managed by the municipality are the following: town hall, school, healthcare centre, cultural centre, senior centre, football field, kindergarten, swimming pool, nursing home, pumping and water treatment facilities, sports centre, mortuary, museum, etc. In all the cases studied, the municipalities had the same facilities, all of public ownership.

The building typologies, according to the number of floors of the buildings and the urbanism, are very similar and uniform for the municipalities smaller than 6000 inhabitants, the sample analysed [20]. This implies that there is a direct relationship with its surface area. This is not true in municipalities with larger population, where, depending on the number of buildings and the number 
of floors they have, as well as the green areas and/or historical urban areas, the relationship between the surface they occupy, and the number of inhabitants is much more variable and it is very much influenced by the factors mentioned above.

According to UNE-EN-16247 standard [21] and the protocol for audits of public lighting installations of the Institute for Energy Diversification and Saving of Spain (IDAE) [22], during the audits all energy consumptions, both electric and thermal, were identified. In addition, the energy consuming elements were inventoried and improvement measures were proposed based on the state of the facilities and the possibility of implementing new technologies. The cost of fuel used for transport, taxes, and fees were not contemplated.

To determine the number of inhabitants, the population data of January 2015 of the National Statistics Institute of Spain was used [23]. The surface area of the municipalities was obtained through the Google Earth Pro (version 7.3.2.5491, Mountain View, CA, USA) tool, and it contrasted with the information available in the Rural Development Service of Badajoz County Council.

For the environmental analysis, the indicator of $\mathrm{kg}$ of total $\mathrm{CO}_{2 \mathrm{eq}}$ was studied, which is conditioned by the Spanish electricity mix (composition of electricity according to the proportion of primary energy used), as well as the conversion factors to primary energy and emission factors of $\mathrm{CO}_{2}$ according to the type of fuel [24]. The values used in the investigation are shown in Table 1.

Table 1. Energy conversion factors.

\begin{tabular}{cccc}
\hline Type & Thermal & Electric & Final to Primary \\
\hline Biofuels & $0.018 \mathrm{~kg} \mathrm{CO}_{2} / \mathrm{kWht}$ & - & - \\
Low temperature solar thermal & 0 & - & - \\
Conventional electricity & - & $0.331 \mathrm{~kg} \mathrm{CO}_{2} / \mathrm{kWhe}$ & $2.368 \mathrm{kWhEP} / \mathrm{kWhEF}$ \\
Solar Photovoltaics & - & 0 & - \\
Diesel & - & - & $1.182 \mathrm{kWhEP} / \mathrm{kWhEF}$ \\
LPG & - & - & $1.204 \mathrm{kWhEP} / \mathrm{kWhEF}$ \\
Natural Gas & - & - & $1.195 \mathrm{kWhEP} / \mathrm{kWhEF}$ \\
\hline
\end{tabular}

In the study, two analyses were carried out: first, the average final energy consumption was studied in terms of four different variables: area of the municipality, number of inhabitants, cost of energy, and annual $\mathrm{CO}_{2}$ emissions. Subsequently, to obtain detailed results of the data used in this investigation, a statistical analysis based on variance (ANOVA) was used, using the factors shown in Table 2. In this sense, the ANOVA test requires that the samples follow a normal distribution and have the same variance. Normality was confirmed by the Levene test [25], taking into account that if the $p$-value obtained in this test is higher than the $95 \%$ level of significance, the hypothesis of normality cannot be rejected and, therefore, it is assumed as true.

On the other hand, statistical regression and correlation techniques were also used to estimate the relations among the variables, studying the conditional expectation of the dependent variable given the independent variables, that is, the average value of the dependent variable when the independent variables are fixed. The variation of the dependent variable around the regression function was also characterized.

Outliers values [26] were detected considering atypical values of all those that were outside the range $\mu \pm 3 \sigma$, where $\mu$ is the average energy consumption based on the number of inhabitants and the area of the municipality and $\sigma$ its standard deviation. 
Table 2. Distribution regarding factors.

\begin{tabular}{|c|c|}
\hline Factors & Distribution Regarding Factors \\
\hline Number of inhabitants $(\mathrm{NH})$ & $\begin{array}{l}\text { HN1: } 200-1500 \\
\text { HN2: } 1501-2500 \\
\text { HN3: } 2501-4000 \\
\text { HN4: } 4001-6000\end{array}$ \\
\hline Surface $(S)$ & $\begin{array}{l}\text { SM1: } 0.08 \mathrm{~km}^{2}-0.40 \mathrm{~km}^{2} \\
\text { SM2: } 0.41 \mathrm{~km}^{2}-0.80 \mathrm{~km}^{2} \\
\text { SM3: } 0.81 \mathrm{~km}^{2}-1.20 \mathrm{~km}^{2}\end{array}$ \\
\hline Geographic Location (GL) & $\begin{array}{l}\text { GL1: North } \\
\text { GL2: Center } \\
\text { GL3: South }\end{array}$ \\
\hline Energy Type (ET) & $\begin{array}{l}\text { ET1: } 0 \% \text { Renewable } \\
\text { ET2: } 10 \% \text { Renewable } \\
\text { ET2: } 20 \% \text { Renewable }\end{array}$ \\
\hline Heating Degrees Days (HDDY) & $\begin{array}{l}\text { HDDY1: } 500-800 \\
\text { HDDY2: } 801-1100 \\
\text { HDDY3: } 1101-1400 \\
\text { HDDY4: } 1401-1700\end{array}$ \\
\hline
\end{tabular}

\section{Results}

In this section, the following results are presented. First, the correlation analyses between the final annual energy consumption of a municipality and the indicators considered in the study (area, number of inhabitants, annual cost of energy, and annual $\mathrm{CO}_{2}$ emissions). Secondly, the results of the analysis of the variance (ANOVA) are detailed according to the factors listed in Table 2. Third, reference indicators are proposed to measure the energy consumption of a municipality, based on the variables analysed and the multivariate regression analysis carried out.

\subsection{Relationship between the Average Annual Consumption of Final Energy and the Number of Inhabitants of a Municipality}

Figure 2 shows the relationship between the number of inhabitants and the average annual final energy consumption of the municipalities studied; it is observed that the energy consumption increases proportionally with the number of inhabitants $(R=0.8944)$.

The line of adjustment corresponds to Equation (1):

$$
\mathrm{C}=0.181 \mathrm{NH}+117.61
$$

where $C$ is the average annual energy consumption of a municipality expressed in MWh per year and $\mathrm{NH}$ is the number of inhabitants of the municipality.

Through this equation it possible to determine the annual average consumption of a municipality by knowing only its number of inhabitants. It is valid for municipalities with a population between 200 and 6000 inhabitants.

Figure 3 shows the relationship between the average annual consumption of final energy per inhabitant and the number of inhabitants of a municipality.

It was observed that the energy consumption per capita tends to decrease as the number of inhabitants of a municipality increases.

Figure 4 shows the annual energy expenditure of each municipality based on its number of inhabitants, which is conditioned by the rates corresponding to the energy consumption of each municipality. 


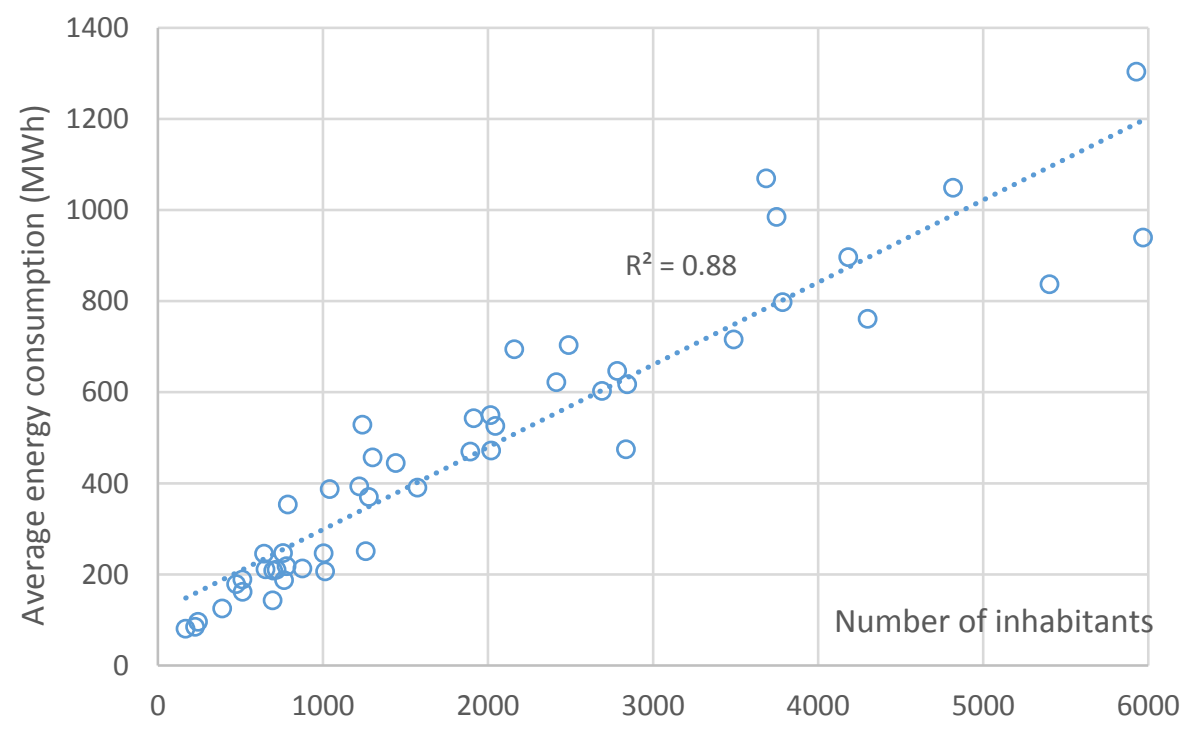

Figure 2. Relationship between the average annual final energy consumption of a municipality and its number of inhabitants.

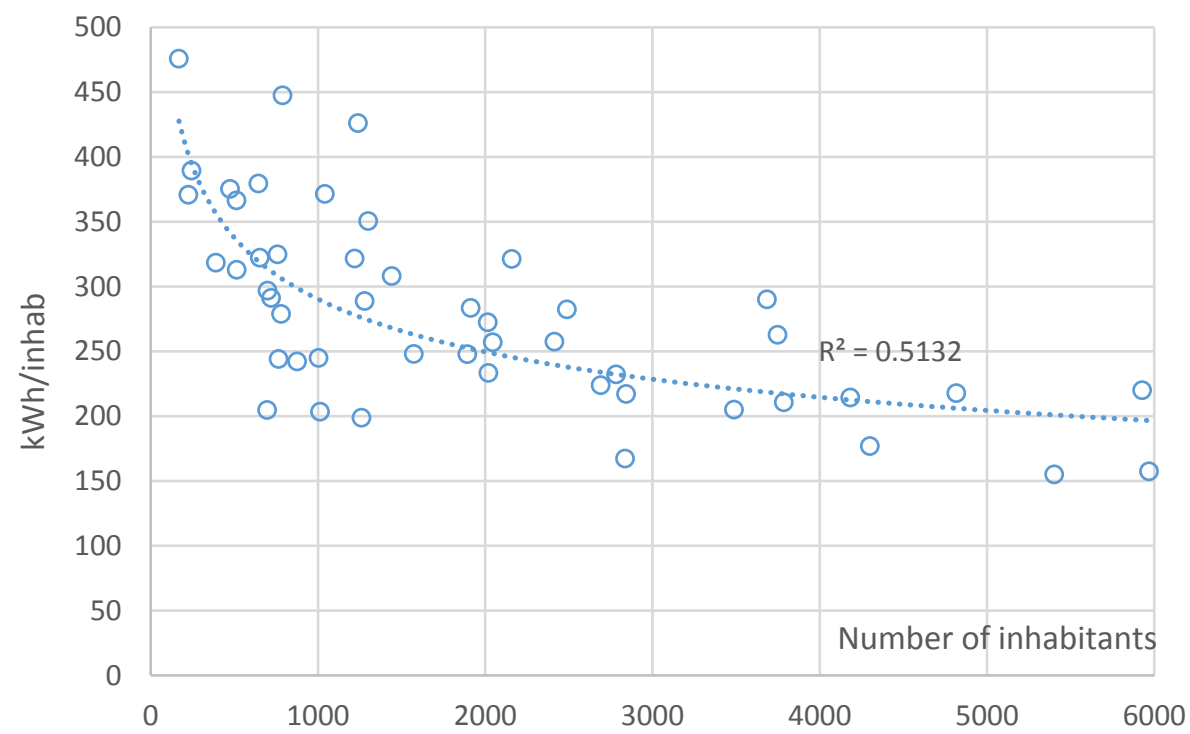

Figure 3. Relationship between the number of inhabitants and the average annual energy consumption of a municipality.

It is observed that, as the number of inhabitants of the municipality increases, so does its annual expenditure $(R=0.9166)$. The existence of a great dispersion was observed, which becomes more evident in populations of less than 2500 inhabitants. It is interesting to show that the per capita cost can be more than 10 times more per inhabitant in municipalities of similar size.

It was found that municipalities with more than 3000 inhabitants obtain average energy prices approximately $10 \%$ lower than smaller ones. It was also observed that municipalities within the range of 5000-6000 inhabitants pay $49.65 \%$ less for the energy cost of their municipal services, compared to those with populations lower than 1000 inhabitants. A great variability was observed in the average energy expenditure of the municipality, between 0.11 and $0.25 € / \mathrm{kWh}$, with an average of $0.17 € / \mathrm{kWh}$. The average per capita annual expenditure of all the municipalities analysed was $€ 53.50$ per inhabitant. 


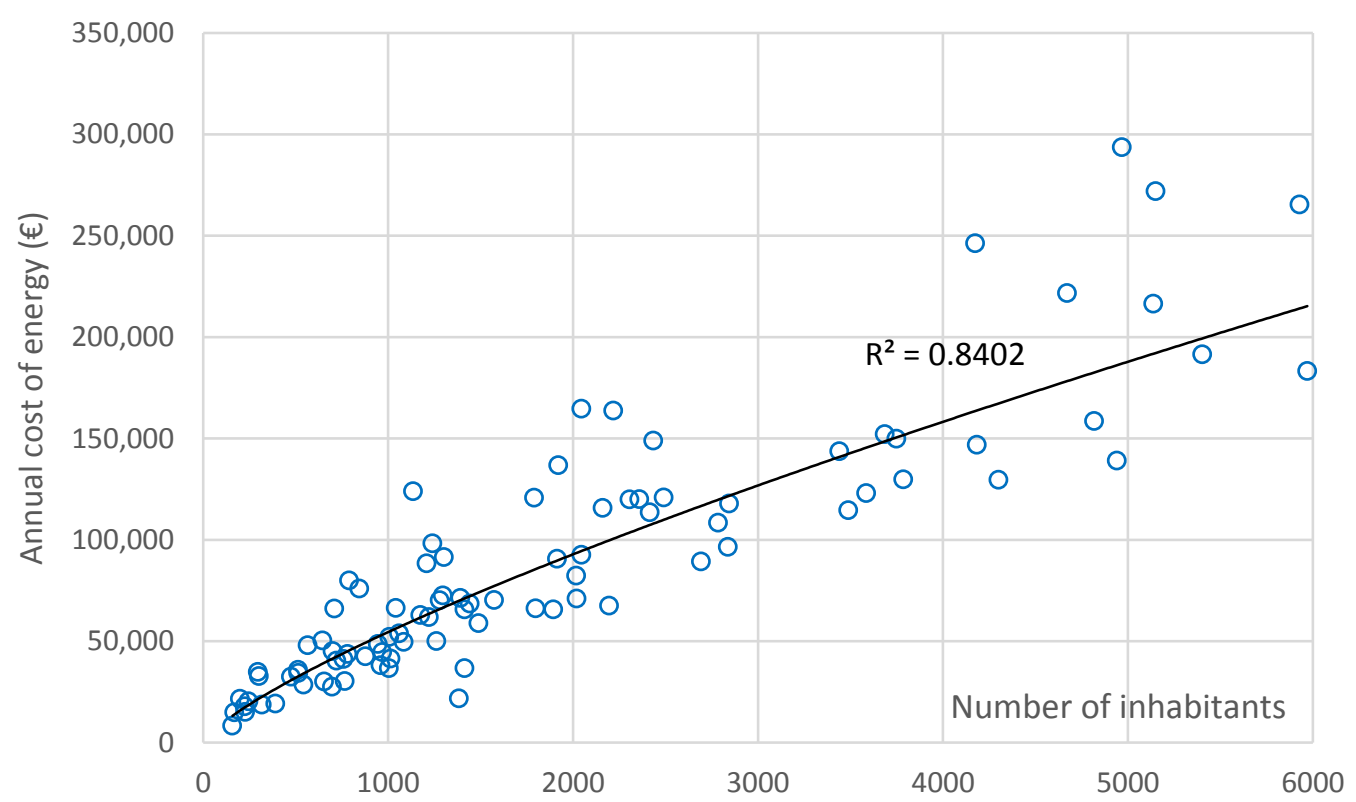

Figure 4. Annual cost of energy according to the inhabitants of a municipality.

3.2. Relationship between the Average Annual Consumption of Final Energy and the Area Occupied by the Municipality

Figure 5 shows the relationship between the surface area of the municipality and its average annual consumption of final energy.

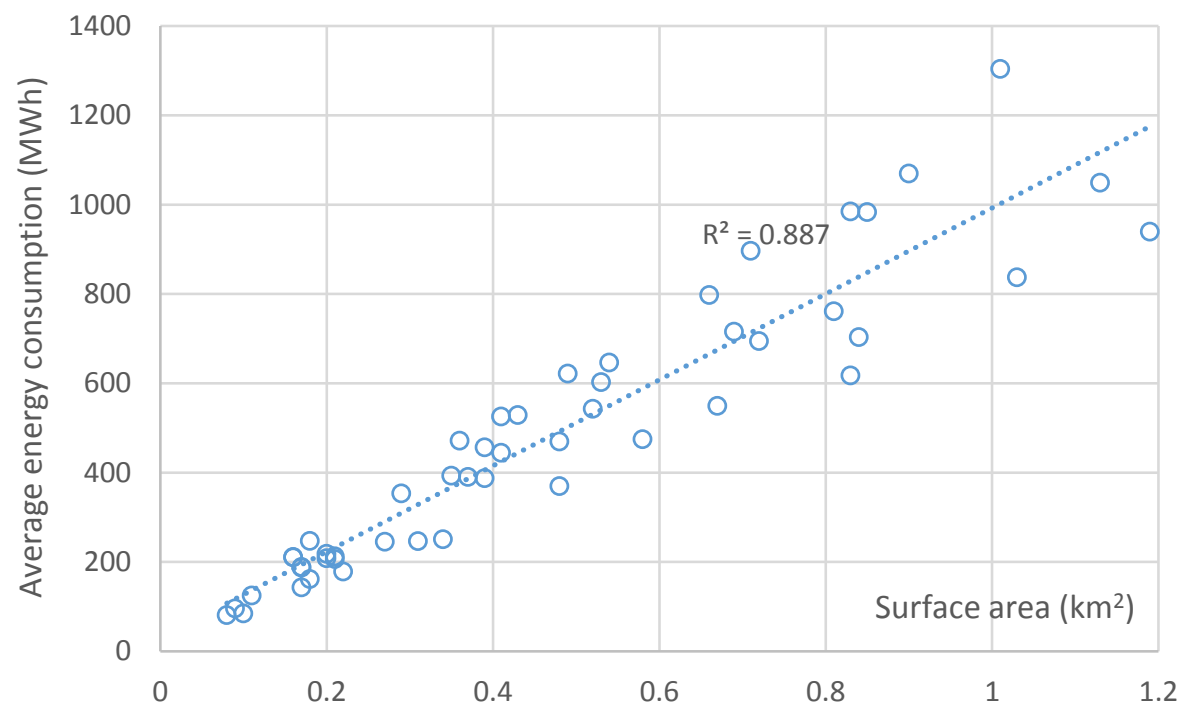

Figure 5. Relationship between the average annual final energy consumption of a municipality and its surface area.

It is observed that as the surface of the municipality increases, so does its energy consumption $(R=0.9418)$, as shown in Equation (2):

$$
C=961.78 S+30.72
$$

where $C$ is the municipal annual energy consumption in MWh per year and $S$ the surface area of the municipality in $\mathrm{km}^{2}$. 
Through this equation it possible to determine the annual average consumption of a municipality by knowing only its surface area. This equation is valid for municipalities with a surface between 0.08 and $1.20 \mathrm{~km}^{2}$.

Figure 6 shows the relationship between the surface of the municipality and its energy expenditure.

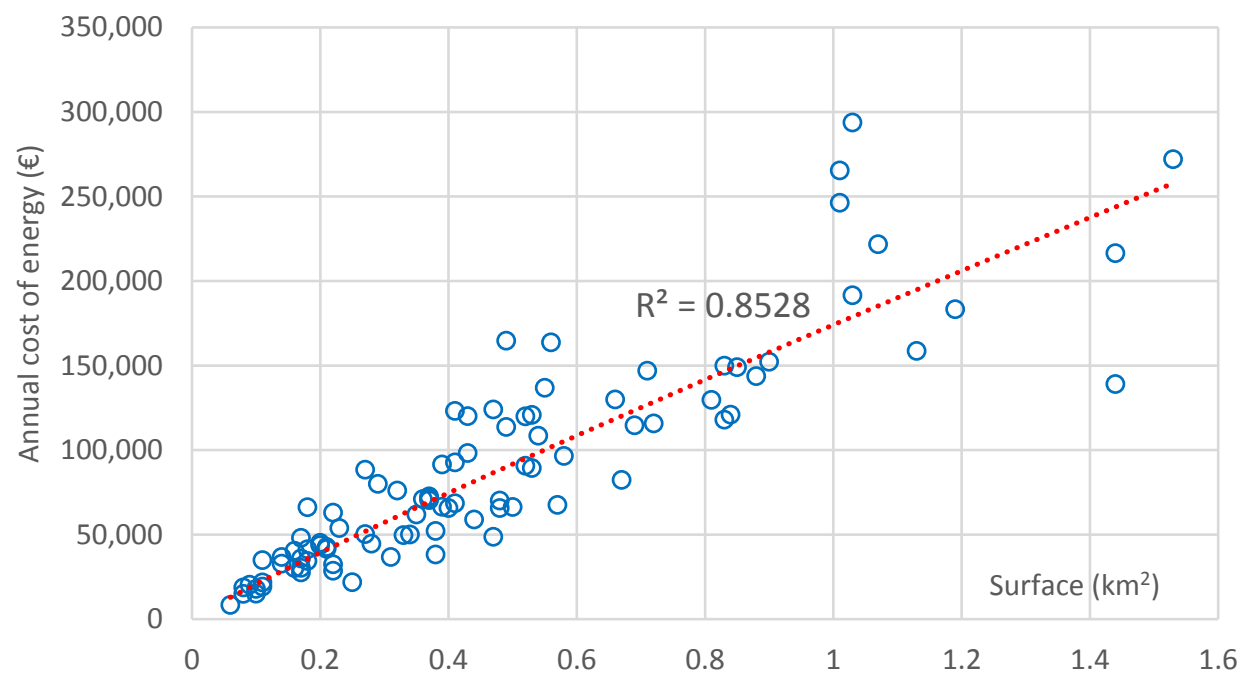

Figure 6. Cost of annual energy according to the surface of a municipality.

It is observed that as the surface of the municipality increases, so does the cost of energy $(R=0.9234)$. However, it can be observed that in municipalities with the same area, the costs can vary significantly, and this fact becomes more evident for areas of less than $0.5 \mathrm{~km}^{2}$, finding differences in costs of up to three times more for the same surface.

\subsection{Relationship between the Average Annual Final Energy Consumption of a Municipality and its $\mathrm{CO}_{2}$ Emissions}

Figure 7 shows the relationship between the final average energy consumption and the annual $\mathrm{CO}_{2}$ emissions of the municipalities analysed in the sample.

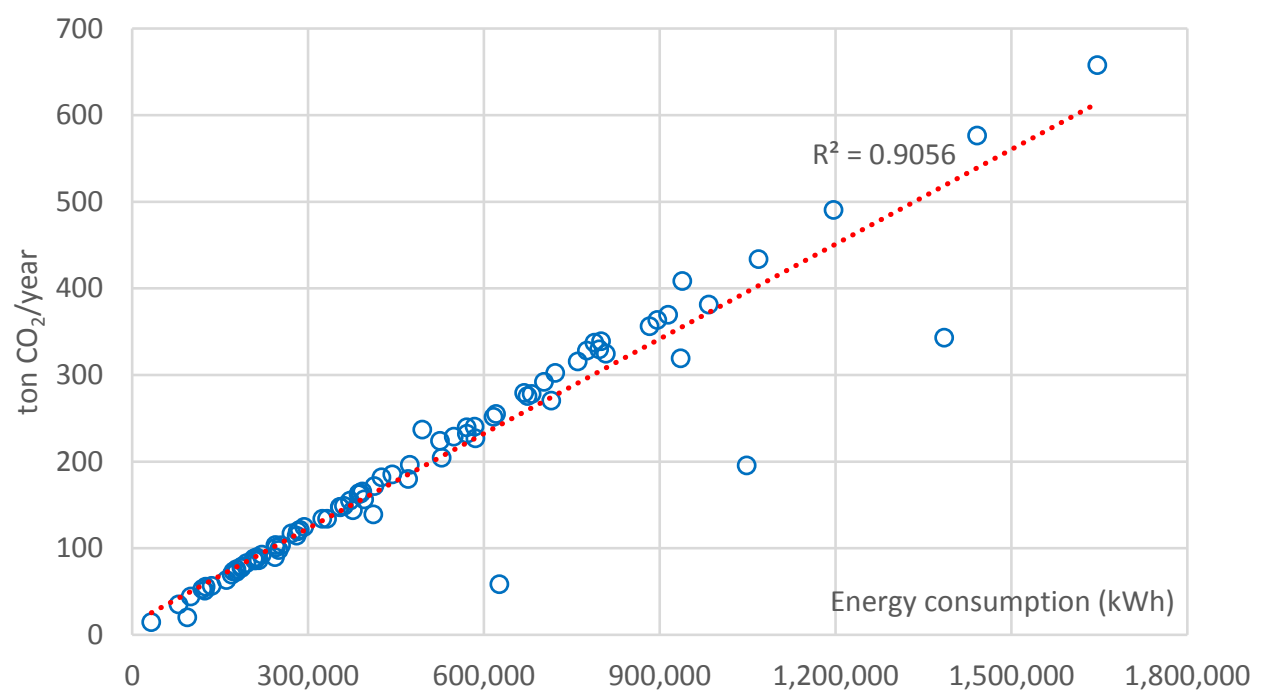

Figure 7. Average annual energy consumption of a municipality and its $\mathrm{CO}_{2}$ emissions. 
It was observed that, as the energy consumption of a municipality increases $(R=0.9516)$, so does the $\mathrm{CO}_{2}$ emissions according to Equation (3). There are three municipalities with $\mathrm{CO}_{2}$ emissions below what would correspond to their energy consumption; the explanation is that all three have biomass heating systems:

$$
E T=0.0004 C+13.49
$$

where $C$ is the annual average consumption of final energy of a municipality expressed in $\mathrm{kWh}$ and $E T$ annual $\mathrm{CO}_{2}$ emissions expressed in tons.

Through this equation it possible to determine annual average $\mathrm{CO}_{2}$ emissions of a municipality by knowing its annual average consumption of final energy. The annual average consumption of final energy can be calculated by Equations (1) or (2).

It is observed that there are municipalities with ratios significantly lower than those that would correspond according to their consumption, due to the use of renewable energies (mainly biomass boilers). In other cases, in some of these municipalities, energy efficiency actions on street lighting have already been carried out [27]. The ratio of $\mathrm{CO}_{2}$ emissions per inhabitant decreases as the number of inhabitants increases.

\subsection{Statistic Analysis}

The results obtained from the statistical analysis of variance (ANOVA) are presented below. In particular, this analysis studies the relationship between the factors listed in Table 2 and the average annual final energy consumption in a municipality of the province of Badajoz (Spain), in relation to the three variables analysed (surface area built, number of inhabitants and $\mathrm{CO}_{2}$ emissions). Table 3 shows the $p$ values obtained in the analysis of variance. To determine if any of the differences between the mean values is statistically significant, the value of $p$ is compared to the level of significance to evaluate the null hypothesis. A level of significance of $\alpha=0.05$ has been considered for this study. If the $p$-value is less than or equal to the significance level, that is, $p \leq 0.05$, the null hypothesis can be rejected, and it could be concluded that not all population mean values are equal. Otherwise, if the value of $p$ is greater than the level of significance, there is not enough evidence to reject the null hypothesis that the population mean values are all the same.

Table 3. Results for the $p$ corresponding to the ANOVA for the average annual energy consumption for a 0.05 level of significance.

\begin{tabular}{cccccc}
\hline \multirow{2}{*}{ Consumption Ratios } & \multicolumn{5}{c}{ Experiments } \\
\cline { 2 - 5 } & $\begin{array}{c}\text { Number of } \\
\text { Inhabitants }\end{array}$ & $\begin{array}{c}\text { Surface } \\
\text { Area }\end{array}$ & $\begin{array}{c}\text { Type of } \\
\text { Energy }\end{array}$ & $\begin{array}{c}\text { Heating } \\
\text { Degree-Days }\end{array}$ & $\begin{array}{c}\text { Geographic } \\
\text { Location }\end{array}$ \\
\hline $\begin{array}{c}\text { MWh mean energy consumption } \\
\frac{k m^{2} \text { surface area }}{\text { surfion }}\end{array}$ & $0.02 *$ & $0.02 *$ & 0.18 & 0.18 & 0.37 \\
$\frac{\text { mean energy consumption }}{\text { number of habitants }}$ & $0.03 *$ & $0.04 *$ & 0.24 & 0.24 & 0.74 \\
$\frac{T n \text { CO2 year }}{\text { number of habitants }}$ & 0.26 & 0.14 & $0.04^{*}$ & 0.25 & 0.11 \\
\hline
\end{tabular}

* At the 0.05 level, the population means are significantly different.

As can be seen in Table 3, the analysis of the variance, considering as a factor the heating degree-days year (HDDY) and the geographical location, does not show significant differences with the three statistics used. That is to say, no direct relationship of the energy consumption of these factors was identified according to the surface, the number of inhabitants or $\mathrm{CO}_{2}$ emissions of a municipality. Analysing the energy consumption data from the point of view of these factors, we can see that they are very similar in terms of consumption in the municipalities analysed. However, there are some factors in which a direct relationship was identified with the consumption of energy in the municipalities: the number of inhabitants and surface area of the municipality and the type of energy.

Table 3 shows significant differences in consumption ratios per inhabitants and surface area through the number of inhabitants and the surface area of the municipality. The ratio corresponding to 
$\mathrm{CO}_{2}$ emissions of a municipality shows only significant differences based on the type of energy used (conventional or renewable).

The municipalities which use renewable energy emit less $\mathrm{CO}_{2}$ and consume less energy per inhabitant $(p=0.024)$ and per area $(p=0.037)$.

The municipalities that have less single-family homes or isolated homes in its municipal area, consume more energy per inhabitant and area than those with more blocks of buildings $(p=0.047)$.

Municipalities with more than 3000 inhabitants have a lower energy cost per inhabitant than those with less than $3000(p=0.042)$.

Municipalities that have a technician directly in charge of managing energy consumption consume less energy than those that do not $(p=038.035)$.

Per capita consumption tends to decrease as the area of the municipality $(p=0.012)$ and its number of inhabitants $(p=0.008)$ increase.

Municipalities between 200 and 1500 inhabitants contract energy 30\% more expensive than municipalities with more than 1500 inhabitants $(p=0.038)$.

\subsection{Ratios}

Using statistical multivariate regression techniques, the coefficients of Equation (4) were calculated, which determine the average annual energy consumption of a municipality according to the number of inhabitants and the area of the municipality:

$$
C=653 S+0.064 N H+49.3
$$

where $C$ is the annual average consumption of a municipality expressed in MWh, $S$ the area occupied by the municipality expressed in $\mathrm{km}^{2}$ and $\mathrm{NH}$ the number of inhabitants registered in the municipality. This equation is valid for municipalities between 200 and 6000 inhabitants and between 0.08 and $1.20 \mathrm{~km}^{2}$.

Table 4 shows the statistics of the regression. It can be observed how the $\mathrm{R}^{2}$ calculated in the regression (0.9004), is higher than the Pearson coefficient calculated in the correlation between energy consumption and number of inhabitants $(0.8800)$ and surface area $(0.8870)$.

Table 4. Statistics of the regression.

\begin{tabular}{cc}
\hline Statistics & Value \\
\hline Multiple correlation coefficient & 0.94891 \\
Coefficient of determination $R^{2}$ & 0.90044 \\
Adjusted $R^{2}$ & 0.89620 \\
Standard error & 98.3423 \\
\hline
\end{tabular}

In Table 4, it can be observed how the $R^{2}$ calculated in the regression (0.9004), is higher than the Pearson coefficient calculated in the correlation between energy consumption and number of inhabitants $(0.8800)$ and surface area $(0.8870)$. In addition, the standard error is smaller, which indicates that it is more accurate and, therefore, is the equation that should be used to calculate the annual average consumption of a municipality.

This key performance indicator (KPI) can be used to measure energy consumption in a municipality, as it is understandable, measurable and practical in terms of costs and time [28]. Figure 8 shows the resulting probability graph, in which the normality of the data set is contracted and, therefore, the validity of Equation (4). 


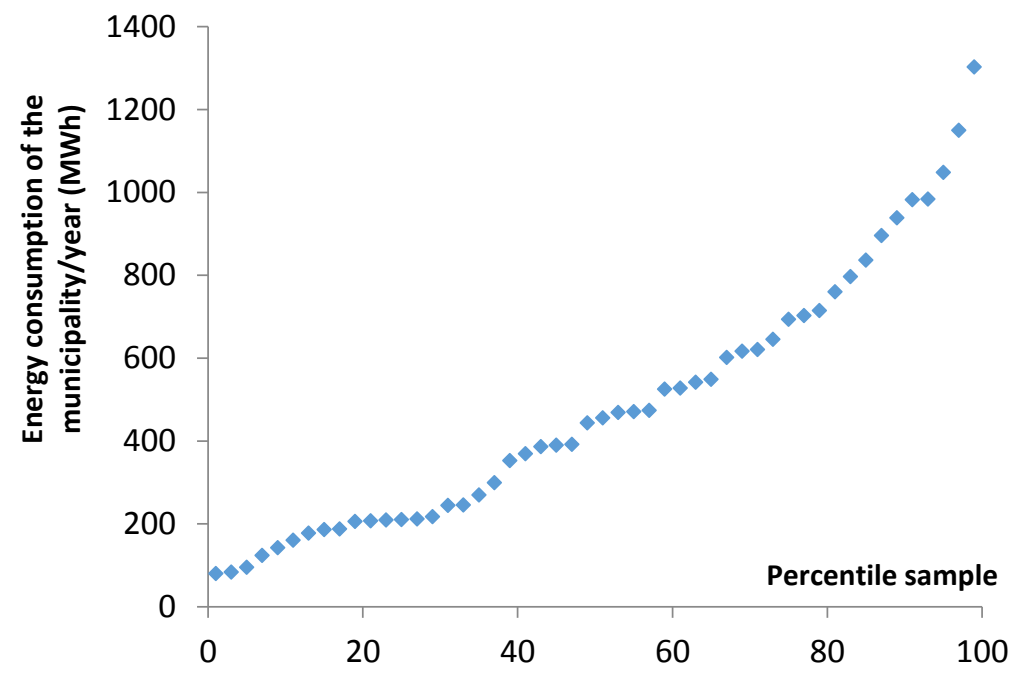

Figure 8. Normal probability test.

\section{Discussion}

The analysis of the real energy consumption of a large sample of municipalities (74 municipalities in this research) and the use of proven statistical techniques ensures that the results are valid for use without the risk of statistical bias. Values lower than $5 \%$ for the error confirm that this research can contribute to the management of energy consumption by assessing real municipality's condition.

This research fills the gap in the state of the art, and it will allow prioritizing investments and identifying each reference municipality consumption by authorities, being able to reward or penalize municipalities whose energy expenditure differs from it.

To determine energy consumption of a municipality in function of the surface area it occupies and its number of inhabitants simultaneously, no previous work have been found. This benchmarking allows determining the real energy situation of a municipality and is valid to implement energy saving techniques [29].

The research results will allow to determining the real energy situation of a municipality and propose operational solutions to implementation of energy saving strategies. It will also be possible to make decisions in relation to the most profitable application of funds for the renovation of municipal facilities from the point of view of energy savings.

The energy consuming facilities in the analysed municipalities are very similar in general, although especially in the case of buildings there are many peculiarities depending on their building typology, use and heating/air conditioning systems that they have [30]. There are some cases that clearly stand out over the energy consumption of the average, either for justified reasons (specific systems such as sewage treatment plants or wells), or because of an obsolescence of the facilities, together with inefficient management and maintenance of them [31]. For example, in the sample several municipalities were detected that consumed more than double of the energy that would correspond according to their number of inhabitants and area. In general, it was observed that the energy management of the municipalities studied can be easily improved.

The public sector should stimulate the efficient management of buildings and provoke changes in the behaviour of energy consumption by citizens and businesses, since reducing the energy consumption of a municipality can free public resources for other purposes [32].

Municipalities should serve as an example in energy efficiency, as it is the best reference to stimulate energy savings among citizens. Cities, as main energy consumers, play a crucial role in achieving a more sustainable energy future [33]. Local authorities play a key role in the energy transition and the fight against climate change, as they govern closer to citizens, and share with regional and national governments the responsibility to fight against climate change [34]. The coordination of 
municipal energy planning at the central level is necessary; strategic energy planning must integrate national policy with municipal energy planning [35].

It was verified that the union of municipalities in commonwealths and entities of purchase would be an adequate strategy, allowing to achieve better energy prices [36,37]. Therefore, the strategy of the municipalities should be oriented towards the formalization of a process of integration of the energy policy [38]. The Covenant of Mayors is an initiative through which towns, cities and regions voluntarily commit themselves to reduce their $\mathrm{CO}_{2}$ emissions through policies that promote energy-saving and renewable energy [39].

It was observed that with equal services, the municipalities with more inhabitants are more efficient and are more likely to have qualified technical personnel to optimize energy consumption [40]. It is surprising that in the range of municipalities with less than 6000 inhabitants with very similar common services, these are provided in smaller municipalities with similar efficiency than in those three or four times their size.

The use of less polluting energy resources, such as solar energy or biomass [41], the reduction of energy consumption due to improved thermal insulation [42], the better use of facilities, and the use of more energy efficient equipment, are alternatives that allow satisfying the demand for comfort indoors, without increasing the energy consumption of buildings. In any case, the way forward must be the decarbonisation of energy-producing systems [43]. However, studies indicate that cost-efficient energy conservation measures are not always implemented, which can be explained by the existence of barriers to energy efficiency [44].

The ratios obtained differ substantially from some references in Spain; for example, in the region of Andalusia an average municipal consumption of $160.5 \mathrm{kWh} /$ inhabitant per year [45] was postulated, which seems unrealistic. It was also observed that the energy consumption of a municipality for street lighting represents a high percentage of expenditure $(>50 \%)$, which coincides with the ratios used in Spain for municipalities with less than 5000 inhabitants, which in 2017 was estimated at $187 \mathrm{kWh}$ per inhabitant and year [46].

It was also found that to reduce the energy consumption of a municipality, it is necessary to continuously know the current status of its facilities and its level of maintenance [47]. For this, it is essential to perform periodic energy audits in municipal buildings [48], and implement energy monitoring and control systems [49]. An interesting measure is to hire technicians or companies specialized in energy management, especially in the smaller municipalities, which have less economic resources and do not have specialized staff [50].

Regarding $\mathrm{CO}_{2}$ emissions per inhabitant, it was observed that in municipalities with a small number of inhabitants, a certain type of facility (for example, a hot swimming pool heated with diesel) could substantially modify the overall emissions of the municipality [51].

It has also been observed that the dissemination of single-family homes in a municipality significantly increases the consumption of electricity, while urban agglomerations have the opposite effect [52]. The dispersion that is occurring rapidly in Spanish municipalities could increase the demand for electricity in the coming years. However, in order to reduce the maximum demand for electricity in the future, the choice of the heating system used is considered to be more important than the reduction in heat demand [53].

The results of the investigation have been showed to the authorities with responsibility for the management of the municipalities, so that they can prioritize the improvement of their facilities and to implement energy saving techniques. In addition, this work is useful to generate incentives or penalties to save energy and to help sensitize the population. The conclusions can be extrapolated to other regions or countries, with similar climatic and organizational characteristics.

Future lines of work should be aimed at studying the advantages of grouping municipalities in terms of savings and energy and environmental efficiency. In addition, it is necessary to deepen the study of the effect of the use of renewable energies in the municipality and to deepen the energy consumption of public lighting installations. 
Based on the obtained results, the most important and appropriate concrete actions that the decisional factors and all the involved parties should take, in order to benefit from research results are the following: using energy audits as usual tool for controlling energy consumption in a municipality, monitoring all the points of energy demand, optimizing energy supply contracts, hiring a technical manager for energy consumption, and making energy benchmarking between the municipalities.

\section{Conclusions}

Energy efficiency and environmental indicators derivate to analyse the energy and environmental situation of the municipalities of the province of Badajoz (Spain) were formulated. Through statistical techniques, it was found that the energy consumption of a municipality is proportional to the surface area it occupies and its number of inhabitants. This benchmarking allows determining the real energy situation of a municipality and is valid to implement energy saving techniques and to prioritize investments in the renovation of the facilities. It was also observed that the annual consumption per inhabitant tends to decrease when the number of inhabitants or surface area increases. It show that the average annual energy consumption of a municipality of less than 6000 inhabitants is $300 \mathrm{kWh}$ per inhabitant and/or $1 \mathrm{kWh}$ per each $\mathrm{m}^{2}$ of municipal area.

As a final result of the research, an equation is proposed that determines the final annual consumption of energy that a municipality must have, based on its surface area and its number of inhabitants, whose validity has been verified for municipalities between 200 and 6000 inhabitants and between 0.08 and $1.20 \mathrm{~km}^{2}$.

One remaining aspect to reflect upon consists in to propose regional strategies that allow rewarding annually the energy saving in the most efficient municipalities.

Author Contributions: Conceptualization: J.G.-S.-C.; data curation: C.S.-V.; formal analysis: D.E.-M.; investigation: C.S.-V., J.G.-S.-C., and D.E.-M.; methodology: J.G.-S.-C.; resources: C.S.-V.; software: C.S.-V.; supervision: J.G.-S.-C.; validation: J.G.-S.-C.; visualization: D.E.-M.

Funding: This research is a dissemination action funded by European project RED URBANSOL, so it has been financed with ERDF Funds through the Cross-Border Cooperation Program Spain and Portugal (POCTEP).

Acknowledgments: The authors wish to acknowledge the Diputación de Badajoz, the University of Extremadura and the Extremadura Energy Agency for the support for this research work. This study has been carried out through the research project GR-18029 linked to the VI Regional Plan of Research and Investigation from the General Government of Extremadura 2017-2020.

Conflicts of Interest: The authors declare no conflict of interest.

\section{References}

1. Directiva 2012/27/UE del Parlamento Europeo Relativa a la Eficiencia Energética y el Plan Nacional de Acción de Ahorro y Eficiencia Energética; Oficina de Publicaciones Oficiales de las Comunidades Europeas: Luxemburg, 2012.

2. Kamenders, A.; Rosa, M.; Kass, K. Low carbon municipalities. The impact of energy management on climate mitigation at local scale. Energy Procedia 2017, 128, 172-178. [CrossRef]

3. Owens, S.; Driffill, L. How to change attitudes and behaviours in the context of energy. Energy Policy 2008, 36, 4412-4418. [CrossRef]

4. Holmgren, K.; Henning, D. Comparison between material and energy recovery of municipal waste from an energy perspective: A study of two Swedish municipalities. Resour. Conserv. Recycl. 2004, 43, 51-73. [CrossRef]

5. Sánchez de Miguel, A.; Zamorano-Calvo, J.; Mosquera de Arancibia, A.; Almazán-González, M. El Alumbrado Público Español, el de Mayor Gasto Eléctrico por Habitante en Europa; Universidad Complutense de Madrid: Madrid, Spain, 2011.

6. Bruckner, T.; Groscurth, H.M.; Kummel, R. Competition and synergy between energy technologies in municipal energy systems. Energy Int. J. 1997, 22, 1005-1014. [CrossRef]

7. Agencia Andaluza de la Energía. Guía de Ahorro y Eficiencia Energética en Municipios; Junta de Andalucía: Sevilla, Spain, 2011. 
8. Poggi, F.; Firmino, A.; Amado, M. Assessing energy performances: A step toward energy efficiency at the municipal level. Sustain. Cities Soc. 2017, 33, 57-69. [CrossRef]

9. Brandoni, C.; Polonara, F. The role of municipal energy planning in the regional energy-planning process. Energy 2012, 48, 323-338. [CrossRef]

10. Rezessy, S.; Dimitrov, K.; Urge-Vorsatz, D.; Baruch, S. Municipalities and energy efficiency in countries in transition: Review of factors that determine municipal involvement in the markets for energy services and energy efficient equipment, or how to augment the role of municipalities as market players. Energy Policy 2006, 34, 223-237. [CrossRef]

11. Sveinbjörnsson, D.; Ben Amer-Allam, S.; Bavnhøj Hansen, A.; Algren, L.; Schrøder Pedersen, A. Energy supply modelling of a low- $\mathrm{CO}_{2}$ emitting energy system: Case study of a Danish municipality. Appl. Energy 2017, 195, 922-941. [CrossRef]

12. Enerintown Project. Monitoring and Control of Energy Consumption in Municipal Public Buildings over the Internet. Programme SAVE, VKA 4.2; Ente Vasco de la Energía: Bilbao, Spain, 2008.

13. Skujevska, A.; Rosa, M.; Kamenders, A. Evaluation of Energy Consumption of Municipal Buildings by Heat Energy Demand Mapping. Energy Procedia 2016, 95, 444-450. [CrossRef]

14. Ferreira, V.G. The Analysis of Primary Metered Half-Hourly Electricity and Gas Consumption in Municipal Buildings. Ph.D. Thesis, De Montfort University, Leicester, England, 2009.

15. Axyonov, S.V.; Silich, M.P.; Skrybin, V.I.; Akhmedov, V.S. Municipalities' energy efficiency estimation approach based on fuzzy models. In Proceedings of the 7th International Forum on Strategic Technology, Tomsk, Russia, 20 September 2012; pp. 1-4. [CrossRef]

16. Fiaschi, D.; Bandinelli, R.; Conti, S. A case study for energy issues of public buildings and utilities in a small municipality: Investigation of possible improvements and integration with renewables. Appl. Energy 2012, 97, 101-114. [CrossRef]

17. Consumo Energético Municipal. Available online: http://www.energiamurcia.es/actuaciones/consumoenergetico-municipal (accessed on 7 July 2018).

18. Bertoldi, P.; Rezessy, S.; Vine, E. Energy service companies in European countries: current status and a strategy to foster their development. Energy Policy 2006, 34, 1818-1832. [CrossRef]

19. Atance-Muñiz, I.; García-Corral, A.; Martínez-Jávega, M.T.; Pujol, R.; Urruela, J. La población rural en España: Un enfoque a escala municipal. Economía Agraria y Recursos Naturales 2010, 10, 35-57. [CrossRef]

20. Segador-Vegas, C. Análisis Cualitativo y Cuantitativo del Comportamiento Energético de los Municipios de la Provincia de Badajoz. Ph.D. Thesis, University of Extremadura, Badajoz, Spain, 2017.

21. AENOR. Norma UNE-EN 16247; Aenor Internacional: Madrid, Spain, 2012.

22. IDAE. Guía Técnica de Eficiencia Energética de Alumbrado Exterior; Instituto para la Diversificación y Ahorro de Energía: Madrid, Spain, 2001.

23. Padrón. Población por Municipios. Available online: http://www.ine.es/dyngs/INEbase/es/categoria. htm?c=Estadistica_P\&cid=1254734710990 (accessed on 14 July 2018).

24. ATECYR. Anuario; Asociación Española de Técnicos en Climatización y Refrigeración: Madrid, Spain, 2016.

25. Samuels, M.L.; Witmer, J.A.; Schaffner, A.A. Statistics for the Life Sciences; Pearson Education: London, UK, 2012.

26. Barnett, V.; Lewis, T. Outliers in Statistical Data; John Wiley \& Sons: Chichester, UK, 1974.

27. Gutierrez-Escolar, A.; Castillo-Martinez, A.; Gomez-Pulido, J.M.; Gutierrez-Martinez, J.M.; Stapic, Z.; Medina-Merodio, J.A. A Study to Improve the Quality of Street Lighting in Spain. Energies 2015, 8, 976-994. [CrossRef]

28. Loosemore, M.; Hsin, Y.Y. Customer-focused benchmarking for facilities management. Facilities 2001, 19, 464-476. [CrossRef]

29. Yoon, S.-H.; Park, C.-S. Objective Building Energy Performance Benchmarking Using Data Envelopment Analysis and Monte Carlo Sampling. Sustainability 2017, 9, 780. [CrossRef]

30. Rodriguez, F.L.; Blazquez, F.C.; Vegas, C.P.S.; Celma, A.R.; Nieto, A.M.; Castro, S.S.; Giancola, E.; Tevar, J.A.F.; Ceramin, M.d.H.; Garcia Sanz-Calcedo, J.; et al. Edificio PETER. Un ejemplo de construcción bioclimática y de integración de energías renovables. Dyna 2011, 86, 212-221. [CrossRef]

31. Asere, L.; Blumberga, A. Government and Municipality Owned Building Energy Efficiency System Dynamics Modelling. Energy Procedia 2015, 72, 180-187. [CrossRef] 
32. García-Sanz-Calcedo, J.; López-Rodríguez, F. Analysis on the Performance of a High Efficiency Administrative Building in Spain. Int. J. Green Energy 2017, 14, 55-62. [CrossRef]

33. Amado, M.; Poggi, F.; Amado, A.R.; Breu, S. E-City Web Platform: A Tool for Energy Efficiency at Urban Level. Energies 2018, 11, 1857. [CrossRef]

34. Del Pablo-Romero, M.; Pozo-Barajas, R.; Sánchez-Braza, A. Analyzing the effects of Energy Action Plans on electricity consumption in Covenant of Mayors signatory municipalities in Andalusia. Energy Policy 2016, 99, 12-26. [CrossRef]

35. Sperling, K.; Hvelplund, F.; Mathiesen, B.V. Centralisation and decentralisation in strategic municipal energy planning in Denmark. Energy Policy 2011, 39, 1338-1351. [CrossRef]

36. Palm, J. Developmet of sustainable energy systems in Swedish municipalities: A matter of path dependency and power relationships. Local Environ. 2006, 11, 445-457. [CrossRef]

37. Fenton, P.; Gustafsson, J.; Ivner, J.P. Sustainable Energy and Climate Strategies: Lessons from planning processes in five municipalities. J. Clean. Prod. 2015, 98, 213-221. [CrossRef]

38. Kostevšek, A.; Petek, J.; Klemeš, J.J.; Varbanov, P. Municipal energy policy constitution and integration process to establish sustainable energy systems-A case of the Slovenian municipality. J. Clean. Prod. 2016, 120, 31-42. [CrossRef]

39. Baldinelli, G.; Bianchi, F.; Cornicchia, M.; D’Alessandro, F.; De Micheli, G.; Gifuni, G.; Monsignori, A.; Ruggiero, M.; Cenci, M.; Bonucci, F.; et al. MuSAE: A European Project for the Diffusion of Energy and Environmental Planning in Small-Medium Sized Municipalities. Sustainability 2015, 7, 16435-16450. [CrossRef]

40. Pitt, D.R. Harnessing community energy: The keys to climate mitigation policy adoption in US municipalities. Local Environ. 2010, 15, 717-729. [CrossRef]

41. Valente, C.; Soldal, E.; Johnsen, F.M.; Verdú, F.; Hanssen, O.J. Methodological accounting tool for Climate and Energy Planning in a Norwegian municipality. J. Clean. Prod. 2018, 183, 772-785. [CrossRef]

42. Carretero-Ayuso, M.J.; García-Sanz-Calcedo, J. Analytical study on design deficiencies in the envelope projects of healthcare buildings in Spain. Sustain. Cities Soc. 2018, 42, 139-147. [CrossRef]

43. Denis, G.; Parker, P. Community energy planning in Canada: The role of renewable energy. Renew. Sustain. Energy Rev. 2009, 13, 2088-2095. [CrossRef]

44. Backman, F. Barriers to Energy Efficiency in Swedish Non-Energy-Intensive Micro- and Small-Sized Enterprises-A Case Study of a Local Energy Program. Energies 2017, 10, 100. [CrossRef]

45. El avance de los Planes de Optimización Energética Municipal. Available online: http: / / www.juntadeandalucia.es/medioambiente/site/ima/menuitem.5893969315ab596f7bbe6c6f5510e1ca/ ?vgnextoid=fda3fc7b4f251210VgnVCM1000001325e50aRCRD\&vgnextchannel= b059958a8551b210VgnVCM2000000624e50aRCRD\&lr=lang_es (accessed on 20 August 2018).

46. IDAE. Inventario, Consumo de Energía y Potencial de Ahorro del Alumbrado Exterior Municipal en España. Available online: http://www.idae.es/sites/default/files/inventario_consumo_y_potencial_ ahorro_alumbrado_exterior_2017_v2.pdf (accessed on 20 August 2018).

47. García-Sanz-Calcedo, J.; Gómez-Chaparro, M. Quantitative Analysis of the Impact of Maintenance Management on the Energy Consumption of a Hospital in Extremadura (Spain). Sustain. Cities Soc. 2017, 30, 217-222. [CrossRef]

48. García Sanz-Calcedo, J.; Cuadros, F.; López-Rodríguez, F. La auditoría energética: Una herramienta de gestión en Atención Primaria. Gac. Sanit. 2011, 25, 549-551. [CrossRef] [PubMed]

49. Lin, Q.G.; Huang, G.H. Planning of energy system management and GHG-emission control in the Municipality of Beijing. An inexact-dynamic stochastic programming model. Energy Policy 2009, 37, 4463-4473. [CrossRef]

50. Polzin, F.; Von Flotow, P.; Nolden, C. Exploring the Role of Servitization to Overcome Barriers for Innovative Energy Efficiency Technologies-The Case of Public LED Street Lighting in German Municipalities; Science Policy Research Unit: Brighton, UK, 2015.

51. Østergaard, P.A.; Vad Mathiesen, B.; Möller, B.; Lund, H. A renewable energy scenario for Aalborg Municipality based on low-temperature geothermal heat, wind power and biomass. Energy 2010, 35, 4892-4901. [CrossRef] 
52. Lasarte-Navamuel, E.; Rubiera-Morollón, F.; Moreno-Cuartas, B. Energy consumption and urban sprawl: Evidence for the Spanish case. J. Clean. Prod. 2018, 172, 3479-3486. [CrossRef]

53. Gustafsson, M.S.; Myhren, J.A.; Dotzauer, E. Potential for district heating to lower peak electricity demand in a medium-size municipality in Sweden. J. Clean. Prod. 2018, 186, 1-9. [CrossRef] 